\title{
Drug Transporters in Toxicology
}

\author{
Belinda Cridge* \\ Department of Toxicology, University of Otego, New Zealand
}

Submission: December 06, 2017; Published: February 06, 2018

*Corresponding author: Belinda Cridge, Department of Toxicology, University of Otego, Dunedin, New Zealand, Email: belinda.cridge@otago.ac.nz

\section{General Overview}

While it has long been accepted that transporters and proteins must exist to move solutes such as drugs across lipid membranes, it is only fairly recently that the nature and properties of the drug transporter proteins involved have come to light [1]. The discovery that these transporter proteins are linked to multi-drug resistance in a range of cancer cells by increasing the removal of chemotherapeutics from out of a cancerous cell, and thereby protecting it, has led to wider research in interest and a rapid increase in the understanding of their form and function and over 400 drug transporter proteins are now known [2, 3]. In pharmacology transport proteins are crucial for moving drug molecules across physiological barriers (e.g. gut lumen, bloodbrain-barrier) allowing both absorption and excretion to occur [4]. Changes in the expression and function of the drug transport proteins is known to alter the basic pharmacokinetic parameters of any given drug molecule and therefore possible inducers and inhibitors can lead to drug interactions [5]. However, their function in toxicology has not been as widely discussed.

\section{What are Transporters?}

Transporter protein is widely classified into two main groups, Solute Carriers (SLC) and ATP-Binding Cassette (ABC) proteins [6]. The SLC are passive solute carriers transporting either anions (Organic Anion Transporters, OAT) or cations (Organic Cation Transporters, OCT) across a membrane generally as an influx mechanism [6]. The ABC transporters use energy from ATP to actively move molecules specifically and/ or against their concentration gradient most often as an efflux mechanism. It is the ATP-transporter family that is particularly associated with the multi-drug resistant phenotype with the most widely cited being p-glycoprotein (P-gp, ABCB1) and the breast cancer resistance protein (BCRP, ABCG2) [7]. ABCB1 has been historically associated with the absorption of drugs and molecules across the intestinal lumen but it is now known to have a wide distribution across the body including functional expression in the blood-brain-barrier, kidney, liver, placenta and testes [8]. ABCG2 expression is linked with cancer cells where its up-regulation can result resistance to chemotherapeutics such as doxorubicin [2] however, similar to ABCB1, it is also located in the liver, intestine, brain, placenta and kidney [9]. While the bulk of research to date has focused on transporter expression in humans (and model species such as rat and mouse), the gene sequences of most $\mathrm{ABC}$ transporters is conserved across vertebrates, some invertebrates and some plants $[10,11]$. Analogous genes have been identified in bacteria and fungi [12].

\section{Induction/Inhibition of Transporter Systems}

It is now becoming clear that drug transporter proteins are critical in the movement of endogenous compounds as well as xenobiotics [13]. Similar to drug metabolising enzymes, the function of transporters is critical for normal homeostasis and alternation in transporter activity can have effects beyond drug resistance $[14,15]$. As well as being regulated through DNA transcription (detailed below) a variety of substrates have been shown to induce (e.g. rifampin, carbamazepine, St Johns' Wort) or inhibit (e.g. erythromycin, ketoconazole, verapamil) drug transporters and therefore affect the action of drugs using these transporters (e.g. digoxin) [16,17]. Similar to drug metabolizing enzymes each individual drug transporter seems to have both a wide substrate preference and also a range of possible inducers and inhibitors, our knowledge of these is really only starting to develop [6].

\section{Regulation (PXR/CAR/AhR)}

Regulation of DNA transcription is transporter specific and can include regulation through the TATA or CCAAT/CT rich promoter sequences [18]. Regulation by p53, AP-1, the Ras/ Raf pathway and APC have also been reported [18]. There is growing evidence of co-regulation of drug metabolism and transport with clear overlaps of transporter expression with the induction/inhibition of CYP3A in particular [19]. Drug metabolising enzymes are often up-regulated in response to environmental signals and there is increasing evidence of co-regulation of drug metabolizing enzymes with the efflux transporters (ABC transporters) [20]. Key to this interaction is nuclear receptors such as the pregnane-X receptor (PXR) and Constitutive Androstane Receptor (CAR). Both the CAR and the PXR receptors are involved in the regulation of enzymes such as CYP3A and also seem to form the basis of cross-talk between enzyme and transporter function [21]. For example, the PXR ligand (and CYP3A inducer) chloropyrifos caused 
increased ABCB1 expression in killifish (Fundulus heteroclitus) hepatocytes [22,23]. For this reason, it has become common practice to presume that CYP3A inducers/inhibitors will affect drug transporter action but the actual relationship is likely to be more complex [24]. Additionally, regulation of the drug transporter proteins via the Aryl-Hydrocarbon Receptor (AhR) has been reported [25]. The AhR is most closely associated with dioxin toxicity and its associated effects on sex ratios [26]. The discovery that drug transporters, as well as the classical induction of CYP1A, may be affected by AhR ligands may open a new line of investigation into potential toxic pathways for these substances. Beyond these specific receptor-mediated effects, recent evidence suggests that drugs widely associated with clinical toxicology, such as acetaminophen, impact transporter function but the mechanisms and implications of this are not widely accepted or understood [27].

\section{Cisplatin}

The most widely cited example of drug transporters in toxicology is their role in cisplatin toxicity in the kidney. Cisplatin is a widely-used platinum-based chemotherapeutic which is taken into cells by the OCT2 transporter [28]. The expression of this transporter specifically in the proximal tubule of the kidney and cochlea hair cells has been directly linked with toxicities in these tissues [29]. The uptake of cisplatin into the cell causes a toxic cascade through their targeting of DNA within the nucleus [28]. Interestingly, hepatic toxicity is not reported with cisplatin due to the preferential expression of OCT1 which does not transport the cisplatin drug [30]. This expression pattern mirroring toxic symptoms remains one of the clearest cases demonstrating the importance of drug transporters in toxicology.

\section{Environmental Toxicology}

Discussion on the role of drug transporters in human health and drug uptake/excretion dominates the literature, however these transporters are vital protective mechanism that prevent absorption or remove toxins from animals, plants and microorganisms. The accumulation of cisplatin into kidney cells highlights the role of transporters in the movement of heavy metals. Evidence from plants suggests that these systems have a wider role in the removal of heavy metal contamination from cells thereby protecting them from potentially toxic accumulation $[31,32]$. The identification of multiple $A B C$ transporters in fish species suggests that these organisms may be susceptible to a range of chemical contaminants (e.g. oil) and that marine species may be more widely affected by the contamination of waterways with sewage containing waste human drugs than has been previously thought $[8,33]$. The toxicology of mixtures is complex but evidence is growing that compounds that inhibit transporter molecules can lead to sensitization to a wide range of other pollutants [34]. Recent studies have confirmed that in yellow fin tuna (Thunnus albacares) pollutants such as polybrominated diphenyl ether can bind directly to transporter proteins and inhibit their action [35]. A similar interaction, through possible inhibition of the $\mathrm{ABC}$ transporters, is being investigated an underlying cause of honey bee colony collapse through increased sensitivity to ivermectin due to concomitant exposure to inhibitors such as quercetin or fungicides [36-41]. This role of the transporters in sensitisation to other chemical entities is likely to become more of an issue as we better understand transporter roles and functions.

\section{Summary}

Overall, our knowledge of the drug transporters (SLC and $\mathrm{ABC}$ ) are growing, however we still lack good understanding of their roles beyond drug metabolism. Furthermore, as safety toxicology moves into a more cell-based predictive model, developing a better understanding of the regulation and expression of these molecules is vital. Additionally, we need to develop a better understanding of the interactions that can lead to chemical sensitisation via alteration of transporter function.

\section{References}

1. Daughton CG, Ternes TA (2001) Pharmaceuticals and personal care products in the environment: overarching issues and overview. Environ Health Perspect 107(Suppl 6): 907-938.

2. Abbott BL (2006) ABCG2 (BCRP): ABCG2 (BCRP): a cytoprotectant in normal and malignant stem cells. Clin Adv Hematol Oncol 4(1): 63-72.

3. Hamdoun AM, Griffin FJ, Cherr GN (2002) Tolerance to biodegraded crude oil in marine invertebrate embryos and larvae is associated with expression of a multixenobiotic resistance transporter. Aquat Toxicol 61(1-2): 127-140.

4. Srinivas M, Thirumaleswara G, Pratima S (2017) Cytochrome p450 Enzymes, Drug Transporters and their role in Pharmacokinetic DrugDrug interactions of Xenobiotics: A Comprehensive Review. Peertechz J Med Chem Res 3(1): 001-011.

5. Wilkens S (2015) Structure and mechanism of ABC transporters. F1000Prime Rep 7: 14.

6. Rengelshausen J, Göggelmann C, Burhenne J, Riedel KD, Ludwig J, et al. (2003) Contribution of increased oral bioavailability and reduced nonglomerular renal clearance of digoxin to the digoxinclarithromycin interaction. Br J Clin Pharmacol 56(1): 32-38.

7. Kim RB (2002) Drugs as P-glycoprotein substrates, inhibitors, and inducers. Drug Metab Rev 34(1-2): 47-54.

8. Dean M, Annilo T (2005) Evolution of the ATP-binding cassette (ABC) transporter superfamily in vertebrates. Annu Rev Genomics Hum Genet 6: 123-142.

9. Miller RP, Tadagavadi RK, Ramesh G, Reeves WB (2010) Mechanisms of cisplatin nephrotoxicity. Toxins (Basel) 2(11): 2490-2518.

10. Eberl S, Renner B, Neubert A, Reisig M, Bachmakov I, et al. (2007) Role of P-glycoprotein inhibition for drug interactions. Clin Pharmacokinet 46(12): 1039-1049.

11. Yan J, Xie W (2016) A brief history of the discovery of PXR and CAR as xenobiotic receptors. Acta Pharm Sin B 6(5): 450-452.

12. Epel D, Luckenbach T, Stevenson CN, MacManus-Spencer LA, Hamdoun A, et al. (2008) Efflux transporters: newly appreciated roles in protection against pollutants. Environ Sci Technol 42(11): 3914-3920.

13. Benet LZ, Cummins CL, Wu CY (2004) Unmasking the dynamic interplay between efflux transporters and metabolic enzymes. Int J Pharm 277(1-2): 3-9.

14. Corsini A, Bortolini M (2013) Drug-Induced Liver Injury: The Role of Drug Metabolism and Transport. J Clin Pharmacol 53(5): 463-474. 
15. Nicklisch SC, Rees SD, McGrath AP, Gökirmak T, Bonito LT, et al. (2016) Global marine pollutants inhibit P-glycoprotein: environmental levels, inhibitory effects, and cocrystal structure. Sci Adv 2(4): e1600001.

16. Giacomini KM, Huang SM, Tweedie DJ, Benet LZ, Brouwer KL, et al. (2010) Membrane transporters in drug development. Nat Rev Drug Discov 9(3): 215-236.

17. Scotto KW (2003) Transcriptional regulation of ABC drug transporters. Oncogene 22(47): 7496-7511.

18. Theodoulou FL (2000) Plant ABC transporters. Biochim Biophys Acta 1465(1-2): 79-103.

19. Li L, He Z, Pandey GK, Tsuchiya T, Luan S (2002) Functional cloning and characterization of a plant efflux carrier for multidrug and heavy metal detoxification. J Biol Chem 277(7): 5360-5368.

20. Borst P, Schinkel AH (2013) P-glycoprotein ABCB1: a major player in drug handling by mammals. J Clin Invest 123(10): 4131-4133.

21. Basseville A, Robey RW, Bahr JC, Bates SE (2014) Breast Cancer Resistance Protein (BCRP) or ABCG2. Drug Transporters: Molecular Characterization and Role in Drug Disposition, Second Edition, pp.187-221.

22. Amacher DE (2016) The regulation of human hepatic drug transporter expression by activation of xenobiotic-sensing nuclear receptors. Expert Opin Drug Metab Toxicol 12(12): 1463-1477.

23. Kim DY, Bovet L, Maeshima M, Martinoia E, Lee Y (2007) The ABC transporter AtPDR8 is a cadmium extrusion pump conferring heavy metal resistance. Plant J 50(2): 207-218.

24. Albertus JA, Laine RO (2001) Enhanced xenobiotic transporter expression in normal teleost hepatocytes: response to environmental and chemotherapeutic toxins. Journal of Experimental Biology 204(2): 217-227.

25. Luckenbach T, Fischer S, Sturm A (2014) Current advances on ABC drug transporters in fish. Comparative Biochemistry and Physiology Part C: Toxicology \& Pharmacology 165: 28-52.

26. Matsuo H, Tomiyama H, Satake W, Chiba T, Onoue H, et al. (2015) Onset age of Parkinson's disease is delayed by a common dysfunctional variant of ABCG2, a major causative gene for early-onset gout. Journal of the Neurological Sciences 357: e279.

27. Dano K (1973) Active outward transport of daunomycin in resistant Ehrlich ascites tumor cells. Biochim Biophys Acta 323(3): 466-483.

28. Nigam SK (2014) What do drug transporters really do? Nat Rev Drug Discov 14(1): 29-44.

29. Kathawala RJ, Gupta P, Ashby CR, Chen ZS (2015) The modulation of ABC transporter-mediated multidrug resistance in cancer: a review of the past decade. Drug Resist Update 18: 1-17.

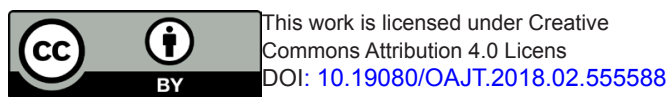

30. Cleophas MC, Joosten LA, Stamp LK, Dalbeth N, Woodward OM, et al. (2017) ABCG2 polymorphisms in gout: insights into disease susceptibility and treatment approaches. Pharmgenomics Pers Med 10: $129-142$.

31. Köhle C, Bock KW (2009) Coordinate regulation of human drugmetabolizing enzymes, and conjugate transporters by the Ah receptor, pregnane $\mathrm{X}$ receptor and constitutive androstane receptor. Biochem Pharmacol 77(4): 689-699.

32. Mandal PK, (2005) Dioxin: a review of its environmental effects and its aryl hydrocarbon receptor biology. J Comp Physiol B 175(4): 221-230.

33. Mao Q, Unadkat JD (2015) Role of the breast cancer resistance protein (BCRP/ABCG2) in drug transport-an update. AAPS J 17(1): 65-82.

34. Guseman AJ, Miller K, Kunkle G, Dively GP, Pettis JS, et al. (2016) Multidrug resistance transporters and a mechanism-based strategy for assessing risks of pesticide combinations to honey bees. PLoS One 11(2): e0148242.

35. Putman M, van Veen HW, Konings WN (2000) Molecular properties of bacterial multidrug transporters. Microbiol Mol Biol Rev 64(4): 672693.

36. Hucke A, Ciarimboli G (2016) The role of transporters in the toxicity of chemotherapeutic drugs: focus on transporters for organic cations. J Clin Pharmacol 56 Suppl 7: S157-172.

37. Agarwal SK, Hu B, Chien D, Wong SL, Salem AH (2016) Evaluation of Rifampin's Transporter- Inhibitory and CYP3A Inductive- Effects -on the Pharmacokinetics of Venetoclax, a BCL 2 Inhibitor: Results of a Single and Multiple Dose Study. J Clin Pharmacol 56(11): 1335-1343.

38. Ciarimboli G, Ludwig T, Lang D, Pavenstädt H, Koepsell, et al. (2005) Cisplatin nephrotoxicity is critically mediated via the human organic cation transporter 2. Am J Pathol 167(6): 1477-1484.

39. Del Sorbo G, Schoonbeek HJ, De Waard MA (2000) Fungal transporters involved in efflux of natural toxic compounds and fungicides. Fungal Genet Biol 30(1): 1-15.

40. Jeon HJ, Lee YH, Kim MJ, Choi SD, Park BJ, et al. (2016) Integrated biomarkers induced by chlorpyrifos in two different life stages of zebrafish (Danio rerio) for environmental risk assessment. Environ Toxicol Pharmacol 43: 166-174.

41. Ronaldson PT, Bauer B, El-Kattan AF, Shen H, Salphati L, et al. (2016) Highlights from the American Association of Pharmaceutical Scientists/International Transporter Consortium Joint Workshop on Drug Transporters in Absorption, Distribution, Metabolism, and Excretion: From the Bench to the Bedside-Clinical Pharmacology Considerations. Clin Pharmacol Ther 100(5): 419-422.

\section{Your next submission with Juniper Publishers will reach you the below assets}

- Quality Editorial service

- Swift Peer Review

- Reprints availability

- E-prints Service

- Manuscript Podcast for convenient understanding

- Global attainment for your research

- Manuscript accessibility in different formats

( Pdf, E-pub, Full Text, Audio)

- Unceasing customer service

Track the below URL for one-step submission https://juniperpublishers.com/online-submission.php 